Historic, Archive Document

Do not assume content reflects current scientific knowledge, policies, or practices. 


$$
\text { ( ) }
$$




\section{FALL PLANTING SUGGESTIONS}

\section{Plant Ehis Fall}

Whatever you are planning to plant, PLANT THIS FALL. Don't wait until Spring-when nursery stock will be scarce, perhaps impossible to obtain at all, and certainly higher in price.

Trees and plants placed in the ground this Fall will have made greater progress by next Summer than those planted next Spring. You gain about six months growth by planting in the Fall.

GLENWOOD NURSERY Trees and Plants are depend- able, healthy, hardy, vigorous and productive. We take extraordinary precautions to keep our stock absolutely free from disease. It is grown in a temperature that makes it sufficiently hardy to thrive in most any climate. No attention is spared to make our stock vigorous and of persistent growth. Whether planted for nuts, fruit, flowers or ornamental foliage, our stock attains a most luxuriant growth, and frequently surpasses our estimation of the limit of its possibilities. And GLENWOOD NURSERY trees and plants always prove to be true to their careful markings.

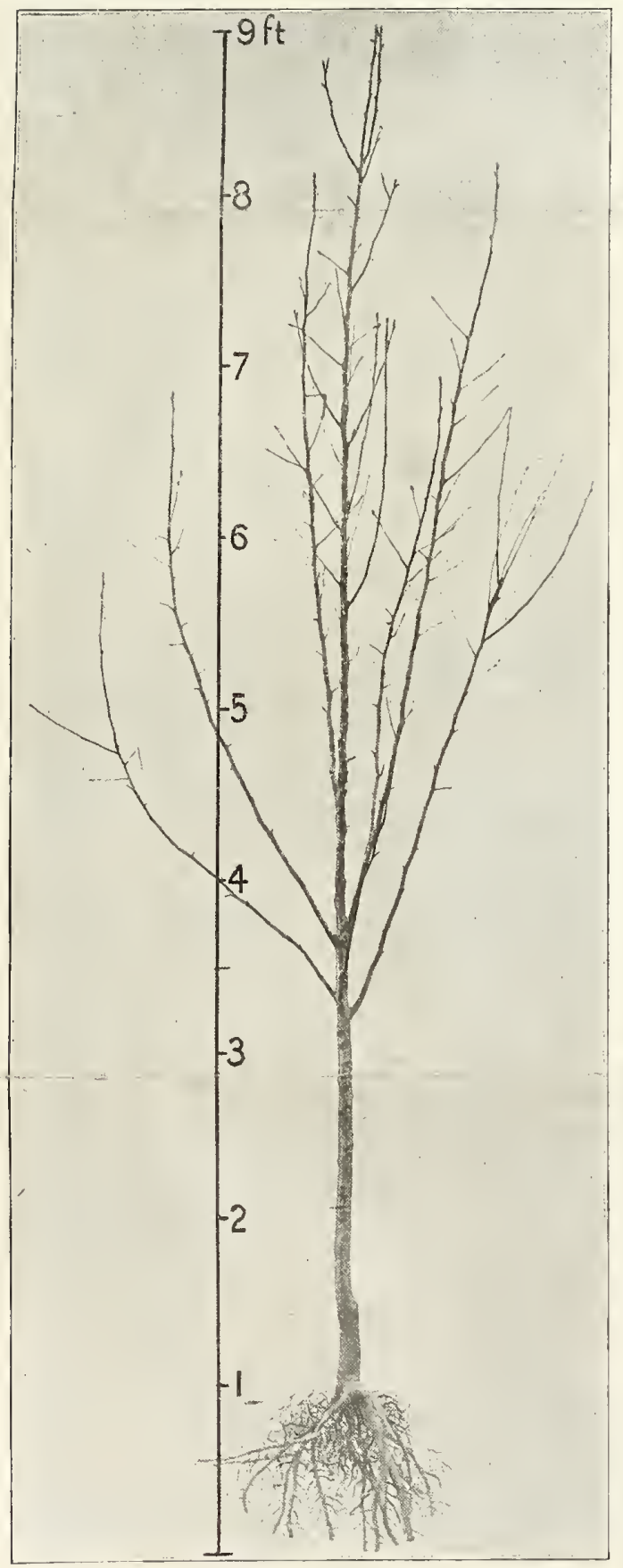

Nut Trees, Fruit Trees, Dwarfs and Standards, Berry Plants, Ornamental Trees, Shrubs, Vines, Evergreens, Hedge Plants

\section{DON'T WAIT A LIFE TIME Plant Large Bearing Age Trees}

\section{Apples,}

EXTRA LARGE, SPECIMEN TREES FOR FALL PLANTING ONLY

If you want fresh, juicy fruit and want it now, and in sufficient quantity to give it a place on the family bill of fare, plant some of these magnificent Bearing Age Fruit Trees which we are offering for the first time this season; trees which are really a horticultural achievement.

Each tree has been grown, cultivated and pruned for a specimen. All of the trees run from seven to nine feet in height; symmetrically branched, heavily rooted-trees that are of bearing age and save you years of waiting

The picture at the side shows a plum tree dug at random from our block of specimens. IF YOU WANT BIG FRUIT TREES FOR IMMEDIATF RESULTS-ORDER TODAY.
APPLES

Autumn

Oldenburg,

Winter

Baldwin,

Northern Spy,

R. I. Greening,

Rome Beauty,

Stayman's Winesap.

$$
\begin{aligned}
& \text { PLUMS } \\
& \text { Early. }
\end{aligned}
$$

Abundance, cherry red, Lombard, violet red, purple, yellow,

$$
\text { Late }
$$

Shrop. Damson, blue, Bradshaw, violet, Burbank, cherry red, October Purple. French Prune, dark Yellow Gage, golden
PEARS

Summer

Bartlett,

Clapp's Favorite,

\section{Autumn}

Duchess,

Sheldon,

Seckel,

\section{Winter}

Anjou,

Kieffer,

Lincoln Coreless.
Prices, $\$ 2.50$ each, $\$ 25.00$ per doz.

Special price in large quantities.

\section{Glen Brothers, Inc., Rochester, N. Y. AUTUMN, 1919}



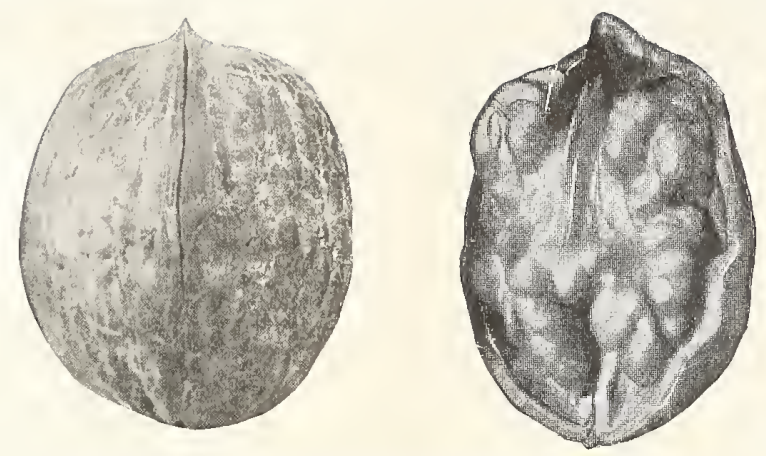

Photograph of Nuts Picked from a Three Year Old Tree Growing at Our Farm

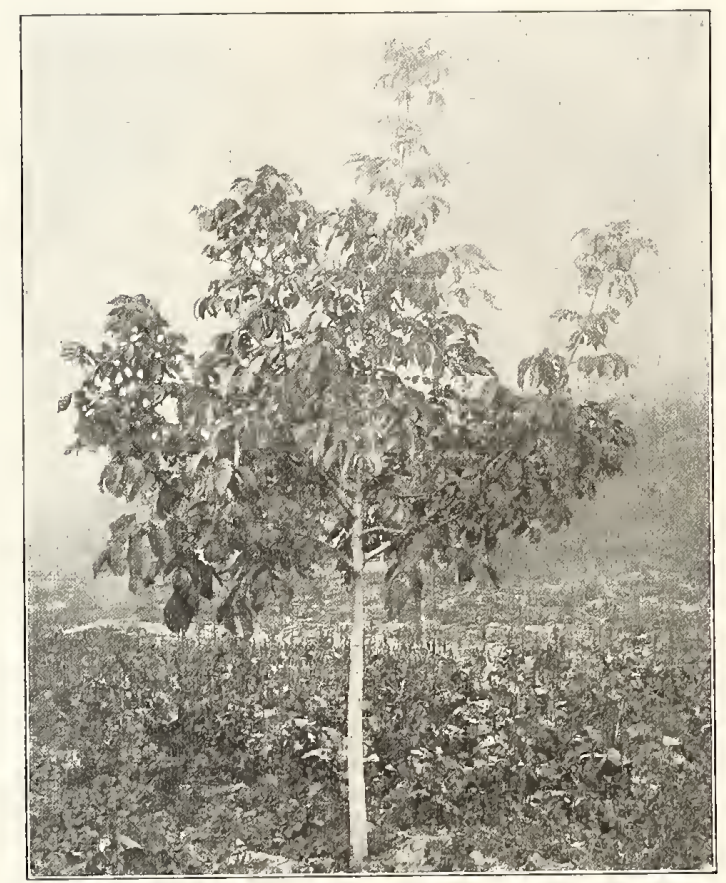

As a Street or Lawn Tree the English Walnut is

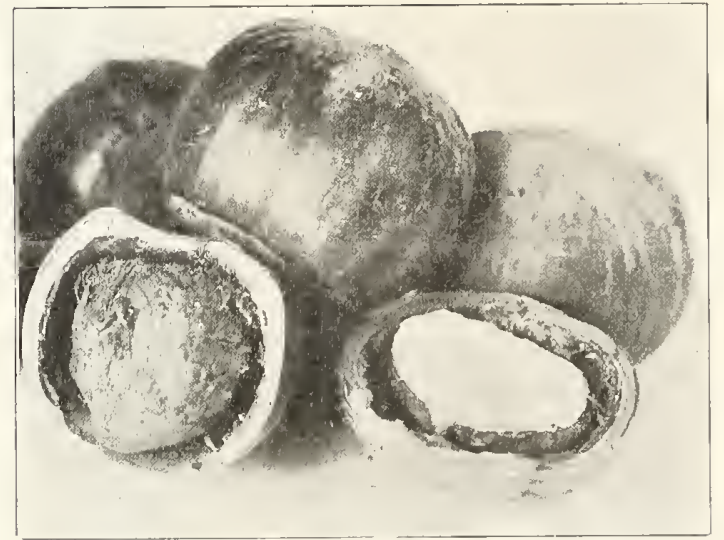

One of Our Best Sellers - the Filberts

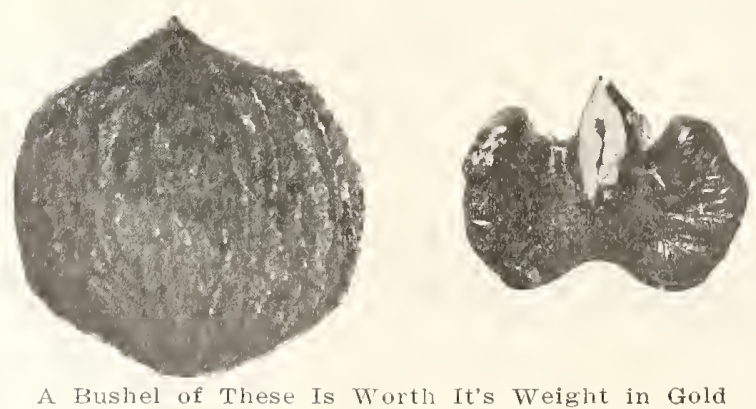

GLEN BROS., Inc., Glenwood Nurseries, Rochester, N. Y.

\section{(10.1......}

\section{English Walnuts for Cold Climates}

It is cold here at Rochester. We have long, bleak winters, temperatures frequently for short periods of twelve to fifteen degrees below zero. Still our hardy, Fairport grown English Walnut trees withstand these cold winters without injury, producing each fall quantities of delicious nuts.

At Avon, N. Y. less than twenty miles from Rochester, one orchard of only 128 English Walnut trees, grown from seed, has produced in a single season two hundred sixty bushels of nuts, thirty-two pounds to the bushel.

Whether you plant one tree or one thousand, our hardy English Walnut trees will give you more pleasure, more satisfaction and greater profits than anything you could plant.

In the Oct. 1915 issue of the American Nut Journal, Dr. W. C. Deming, then Secretary of the Northern Nut Grower's Assn. said with reference to English Walnut trees growing about Rochester, N. Y.

"The trees are there. I urged the local committee . . . . to locate every tree they could so that we might visit them all, but it was soon found that if were to do this we should have to live in Rochester. . . . . It is not unusual to see Walnut trees in the yards of houses that we passed. Most of the trees were large, thrifty and bushy."

We claim that our hardy northern grown trees will grow and produce nuts in any climate not too severe for Peach trees, and in any soil adapted to the growing of Apples, Peaches, Pears, Cherries and other fruits.

The folowing are two of our most popular varieties:

FAIRPORT,-Originated in Rochester. A safe and reliable variety to plant in zero climates. Nut round, fullmeated, of fine quality, thin shelled. Tree is a rapid grower, blooming late. Nuts ripen and fall from tree in September.

THOMSON.-An excellent commercial nut for severe climates. A real paper shell, sweet and delicious, selling at wholesale from 4 to 6 cents per pound more in Rochester markets than do the California nuts.

Price,

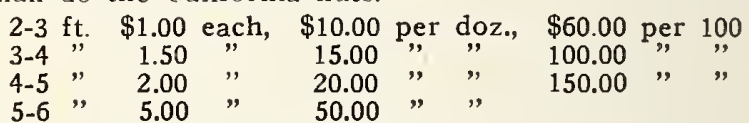

Specimen Tree, $5-6 " 5.00 " 50.00 "$,

EXTRA LARGE ENGLISH WALNUT TREES.-Superb for lawns and driveways. Fr those of our customers who wish to get the earliest possible results both in bearing, age and appearance, we offer this coming spring a few specimen trees that will prove exceptional values.

7-9 ft. $\$ 10.00$ each, 100.00 per doz.

\section{The Filberts}

\section{Strains That Defy Zero Climates}

Filberts raised under the rigorous climatic conditions prevailing in our nurseries, thrive under a wide variety of soils and sections. With us they prove as hardy as Elms and Maples. Amply fortified with strong root systems, with wood of the toughest fibre. Glenwood Nurseries, hardy nut trees have that strength and constructional vigor essential in zero climates.

\section{AMERICAN VARIETIES}

Purple Leaved, (Avellana Atro-purpurea)-Nut large, thin-shelled, delicious one of the best. 'The leaves and husk are of deep purple color, which is retained until frost. Very ornamental.

Hazelnut, (American Filbert)-Bears excellent nuts and in great quantities; also very ornamental.

Price,

$3-4$ ft. $\$ .75$ each, $\$ 7.50$ per doz., $\$ 50.00$ per 100

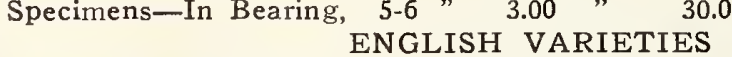

Kentish Cob, (English)-Nut large, oblong, somewhat compressed; kernel plump and of rich flavor. An excellent keeper. Considered the best variety grown in England, where it has been known since 1812.

Cosford, (Paper-shell, Layered Plants From Imported Parent Plants) -Nut oblong, kernel plump and of richest flavor. This variety is very productive and highly prized in Europe because of its thin shell and high quality. Rarely seen in American markets.

Price,

$2-3 \mathrm{ft}, \quad \$ 1.00$ each, $\$ 10.00$ per doz.,

$\$ 65.00$ per 100

Specimens-In Bearing, $5-4, \quad 1.50, " 15.00, ", \quad 100.00, "$,

\section{American Black Walnuts}

AMERICAN BLACK WALNUTS.-The American Black Walnut is one of the most valuable among our timber trees, also a magnificient shade tree, producing a rich, meaty nut, well known to us all in an abstract way perhaps, but not in a personal way that comes from picking up these delicious nuts from your own lawn.

The Black Walnut is hardy everywhere, a rapid grower, coming into bearing five or six years after planting. Our own strain of Black Walnuts propagated from selected thin-shell nuts, produce for the planter a crop as valuable per acre as fruits, with the advantage of being an imperishable product.

Price,

4-5 ft. $\$ 1.00$ each, $\$ 10.00$ per doz., $\$ 75.00$ per 100

Special,

$6-8 " 1.50 " 15.00$

100.00 


\section{The Aces of All Apples DELICIOUS and OPALESCENT}

Every yard and garden in America should contain these two great varieties.

The Apple is the only fruit that one really never tires of. One great advantage in planting the Delicious and Opalescent is that they come into bearing within a very few years. Just close your eyes for a moment and imagine gathering several bushels each season of this choice fruit to eat during the long winter months, as both are strictly winter varieties. The season of the Delicious is November to February and of the Opalescent, December to March.

Plant only one of each if you do not have room for more, but plant a thousand of each if you can.

Delicious.-Large brilliant dark red, flesh fine-grained, crisp, melting, juicy with a delightful aroma. Tree bears heavy crops annually.

Opalescent.-The handsonest Apple ever put on the market. Large to very large; light red, sliading to very dark crimson, with many yellow dots; skin smooth and susceptible to very high polish; flesh yellowish, tender, juicy and good, productive. One of the best varieties we have.

Price for beautiful, budded, two year trees: $\$ 1.00$ each, $\$ 10.00$ per doz.

\section{Dikeman Cherry}

As delicious as the large, black California Cherries one sees in the fruit stores. Bears third year. Look through this circular. If you have room for only one of the trees or plants offered, buy a Dikeman Sweet Cherry.

The Dikeman is bound to please at delivery time, because of its exceptionally handsome appearance, being a strong grower, well topped, and having a trunk as straight as a die. Especially will it give satisfaction when it comes into bearing, on account of its prolificness and exquisite quality of fruit. It is extremely hardy, in fact, will thrive admirably in all sections where Cherries are grown. The Dikeman is rapidly becoming the most popular Black Sweet Cherry grown.

This gem among Cherries lias the advantage of being the latest ripening sweet Cherry known. Black, good size, and in texture reminds one of the Cherries from the Pacific Slope, being meaty and solid.

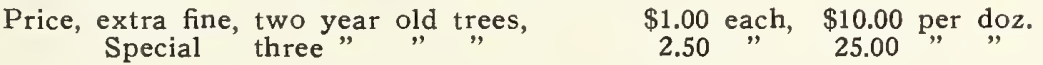

\section{Dwarf Everbearing Apple Collection}

SIX CHOICE VARIETIES OF APPLES ON YOUR TABLE FROM AUGUST UNTIL THE FOLLOWING JUNE

\section{$\$ 5--P l a n t e d$ in a Garden Plot $12 \times 12$, Bears Second Year $-\$ 5$}

Six choice varieties of Apples on your table from August until the following June. An entire Everbearing Apple collection can be raised in your own yard by anyone who has space $12 \times 12$. The following six trees, planted six $\mathrm{ft}$. apart will take the place of an Everbearing Apple tree, which will probably never be produced, and yield a most delicious combination any place where fruit trees may be grown and soil and locality need not be taken into consideration;
1 Red Astrachan,
Season for table use August,
1 Duchess,
1 Wealthy,
1 McIntosh,
1 Northern Spy,
1 Winesap,
September,
October, November,
December to February
January to April,
January to June.

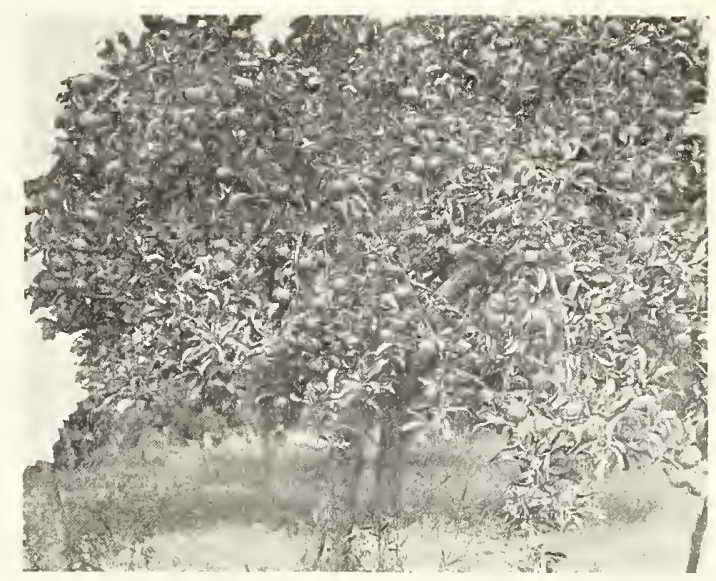

Delicious Apple is a Great Cropper and Comes into Bearing at an Early Age

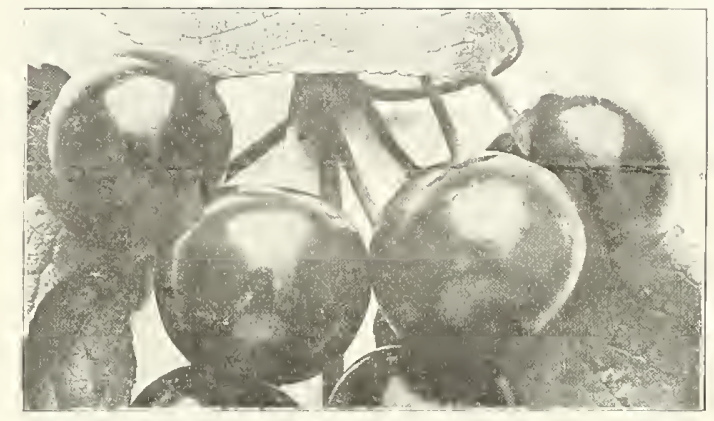

Large, Luscious Dikeman Cherries, and the Trees Are Loaded Every Year

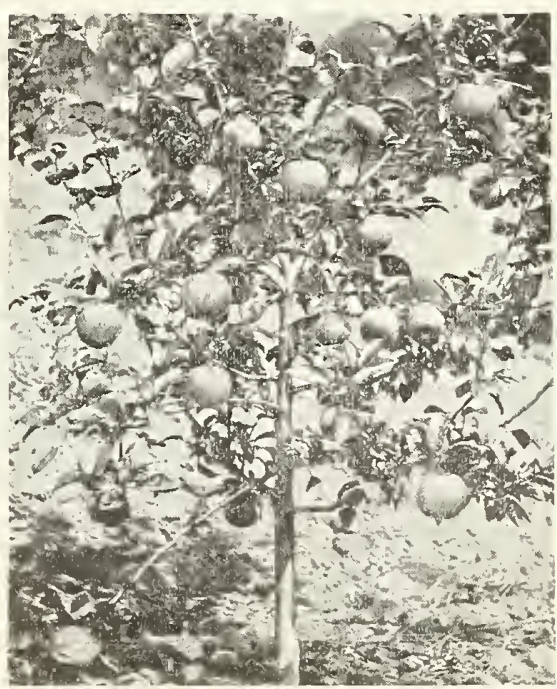

Dwarf Apples Bear Abundantly the Third Year. This Tiny Tree, Only Three Years old Bore 17 Perfect Apples In one Season.

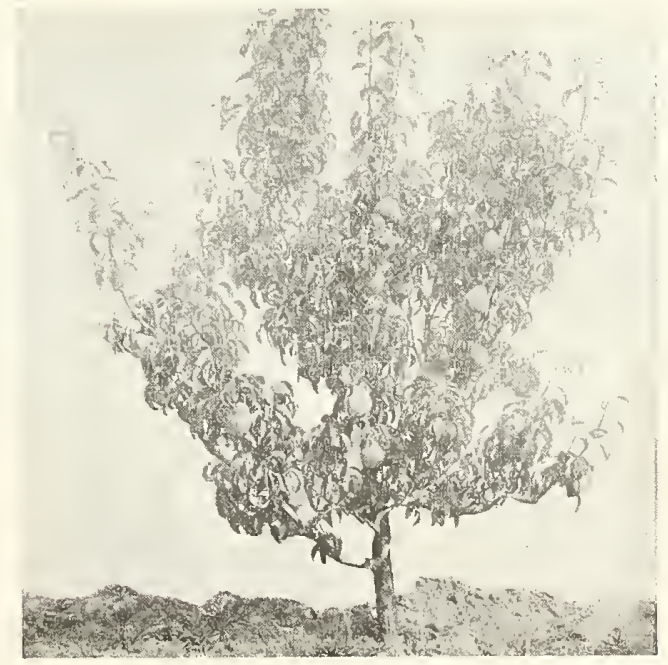

\section{\$3--All Season Dwarf Pear Collection--\$3}

\section{SIX CHOICE VARIETIES FOR $\$ 3.00$}

A few square yards of ground, a few spare hours of work in planting and you may gather next summer and fall all the Pears you want from trees set this fall. A small investment in this collection will allow you to pick an assortment of delicious Pears from July to November, besides having a surplus to keep through February

Koonce,

Wilder Early,

Clapp's Favorite,

Season, July,

Bartlett,

Angouleme,

Anjou,
Early August,

Late August,

September,

October, November,

October to January. 


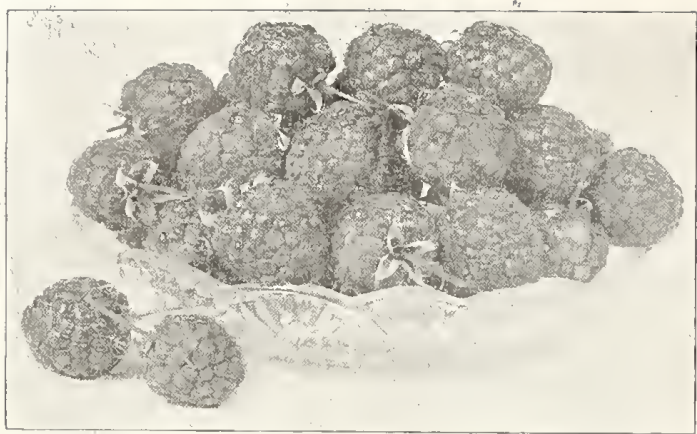

HAS ERSKINE PARK MADE GOOD? The answer:

Aug. 14, 1919

Messrs. Glen Bros. Inc.

Rochester, N. Y.

Gentlemen:-I should like to order another hundred of your Erskine Park Everbearing Raspberry plants. Please let me know what time it is best to plant them. The ones you have sent me have done very well. Two died, the remaining are very satisfactory." Yours truly,

\section{Geo. Crompton,}

Worcester, Mass

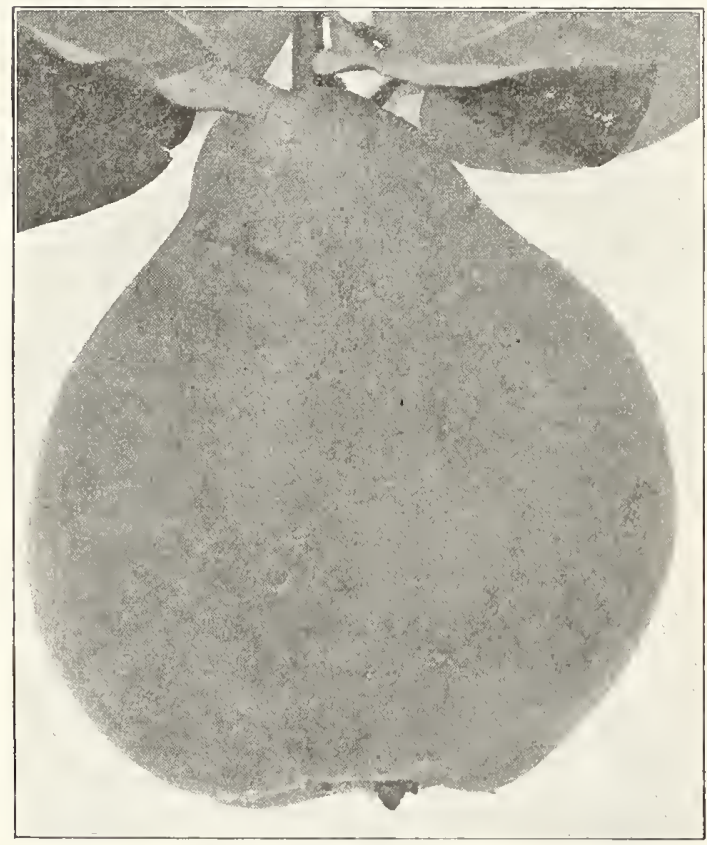

Hase You Ever Taster Baked Quinces? Delicious

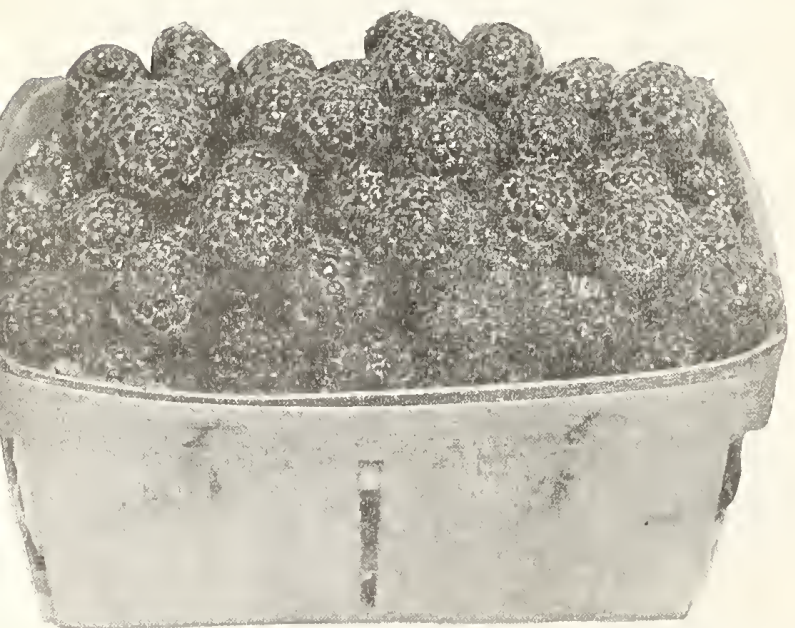

Honeysweet with Sugar and Cream Are Simply Delicious

\section{The Erskine Park Everbearing Red Raspberry}

\section{Plant This Fall-Pick Berries All Through Next Summer}

The Erskine Park Everbearing Red Raspberry is a seedling from the old reliable Cuthbert, discovered on the Westinghouse Estate (Erskine Park) at Lee, Mass by Mr. Edward Norman. This magnificient estate is in the midst of the beautiful Berkshire Hills, with a temperature in winter of 30 or 40 degrees below zero, so that the hardiness of this berry is unquestioned. The estate is surrounded by the summer homes of many wealthy people, and much to the surprise of his neighbor's gardeners and not without a great deal of personal satisfaction, Mr Norman furnished large, luscious raspberries throughout the fall for various dinner parties.

Of this berry we cannot say too much in praise, and we predict that once known, it will be a standard for planting in every garden and considered a necessity

Conceive the joy and satisfaction of having such berries on your table all through the autumn, the source of wonder to your neighbors, that you can pick the finest Raspberries until the snow flies. On Nov. the 20th we cut a large branch of the Erskine Park with blossoms, green berries and ripe fruit upon it.

We have not as yet been able to propagate any large quantity of this magnificient berry, but what we have are the finest Bearing Two Year Old Plants, heavily rooted and branched, that will bring a full measure of pleasure and satisfaction to the planter.

On account of the phenomenal yield of each plant and the huge proportions to which it grows, 110 one needs a large quantity for personal use, twelve to twenty-four plants being enough for the average family.

These berries are commented upon by all who have seen and tasted them as the most delicious and best Raspberry they have ever eaten. Mr. Baker of Hoosick Falls, N. Y, writes us as lollows regarding this remarkable berry:

"In the season of 1916, Mr. Geo. M. Darrow, of the U. S. Dept. of Agriculture, was traveling from the Atlantic to the Pacific, visiting fruit growers to obtain information on berries for builetins published by the Department of Agriculture. Mr: Darrow was at our place both at the beginning of his trip and at the end, and on his way back he spent the night with us. He had spent the summer visiting the different fruit growers of the country and taking hundreds of photographs. Mr. Darrow being 'full' of berries, talked about all the different varieties that he had seen and made a study of on his trip, advised me by all means to try some of this variety. Mr. Darrow had visited this estate before and was most favorably impressed that this berry was far ahead of the St. Regis and Ranere, and when it became known that it would replace these varieties. The plant is by far the strongest growing Raspberry I have ever seen. It branches like a tree, and it also has the largest and most roots of any variety with which I am acquainted. It is perfectly hardy and the berries are very large.

Strong Field Grown Bearing Plants, $\$ 5.00$ per doz., $\$ \$ 30.00$ per 100

\section{The Famous Orange Quince}

The best of the older varieties and more extensively cultivated than any other. Everyone is familiar with the Orange Quince, a good old variety that never disappoints the planter.

Good for home and for market. Its large, golden yellow fruit of fine quality is to be seen in more or less quantites in nearly every garden or orchard every season, as it rarely fails to produce a crop.

The tree is hardy, and compact in growth. Requires but little space, and comes early into bearing. The fruit is much sought after for canning for winter use. When put up in the proportion of about one quart of quinces to four quarts of other fruit it imparts a delicious flavor

We offer fine trees for fall planting. Price, $\$ 1.00$ each, $\$ 10.00$ per doz.

\section{Honeysweet Black Raspberry}

\section{Large Size-Glossy Black Color-Delicious Flavor}

If you want quarts and quarts of delicious black raspberries from your own plants next summer, plant Honeysweet this fall. Honeysweet is the best black raspberry by miles that we have ever seen and we have seen them all. It is perfectly hardy, passing through the severe winter of 1917 and 1918 without injury. It is very productive, the many clusters of big black raspberries seem to cover the bushes. Order some Honeysweet plants to-day for shipment at the proper time for planting this fall. You can get a whole dozen of these plants for $\$ 4.00$, and a dozen is sufficient to supply the average family. Or we will sell you 100 plants for $\$ 25.00$ Don't fail to order a few plants of this new and splendid variety 


\section{Blowers Big Blackberries}

\section{BIGGEST AND BEST MONEYMAKER OF ALL BLACKBERRIES}

Record, $14 \mathrm{ft}$. and 1 in. extreme height of bush, 2694 berries on one bush. 2720 quarts from one-third acre.

On Seven Acres, 30,206 quarts, 45,307 lbs. 943 15-16 bushels, 22 2-3 tons.

$\$ 2,121.75$ net f. o. b. here; $\$ 303.10$ average per acre; 153 bushels netted $\$ 344.25$ from best acre.

THE QUALITY.-Its sprightly, yet moderate acid taste is indicative of the presence of those valuble medicinal properties without which the Blackberry is worthless. A large, clean, bright berry. The fruit is exceedingly sweet, with no perceptible core, when fully developed. The flavor is pleasant without being peculiar. In fact, it is a blackberry from root to tip. It is a first-class shipper, standing up well for several days. Its marvelous size and splendid flavor have called forth the following comments by those who have observed it.

"Was surprised to see the mammoth growth of bush and berry." "Most splendid fruit as to size, color and quantity that ever grew on Blackberry bushes." "The berries are large and handsome, and the flavor good." "You can only appreciate the fruit by seeing our 'berry orchard' in fruiting.

HARDINESS.-Plant Blowers Blackberry anywhere you would grow Concord Grapes.

DISTANCE APART TO PLANT.-Rows $8 \mathrm{ft}$. apart, $3 \mathrm{ft}$. in row. This takes about 1800 plants to the acre.

SEASON OF FRUITING - The season of ripening is from July 25 th until frosts. The bulk of the crop matures in the month of August. The yield in September and October depends upon the season, very few in October. We have had blossoms and ripe fruit in November. Should be planted this fall.

We offer extra fine, two year old Transplants, $\$ 1.50$ per doz., $\$ 10.00$ per 100 .

\section{Asparagus the First Season}

Two years saved by planting four year transplanted roots this fall,

The Asparagus is one of the oldest as well as one of the most delicious of our garden vegatables. It was cultivated in the time of Cato, two hundred years B. C.; and Pliny mentions a sort that grew in his time near Ravenna, of which the heads weigh a pound. From these accounts it appears that there is nothing new under the sun, in the line of Asparagus, except the saving in time.

A great many more people would grow their own Asparagus if it were not for the two ycars of waiting. We eliminate this for the planter by cultivating and transplanting the roots till they are four years old, strong and healthy Downing, no doubt the highest authority, says roots of this age will produce fruit the same season planted.

When we talk about tender Asparagus on your table this coming June, fresh from your own garden, we know that your mouth not only waters but that you look incredulous. Too good to be true, you say! And yet, it can be easily done if you plant some extra large Asparagus roots, such as we have worked over and transplanted for the last four years, purposely ready to get immediate results.

Asparagus may be had any time during the winter if these strong, four-year old roots are stored in a cold place until wanted. They are then covered with a few inches of soil in a hot-bed or green-house and kept very warm. In two weeks the shoots will be several inches long and cuttings may be made for a month.

We offer for fall delivery, extra fine, four-year transplanted roots,

Per dozen, $\$ 1.00$; Per fifty, $\$ 3.50 ; \quad$ Per hundred, $\$ 7.00$

N. B.-Order early before our supply is exhausted.

\section{Champagne Wine Plant--- Rhubarb}

\section{PLANT THIS FALL}

Named becausse of its nine sparkiing flavor. It is the "Ne-plus-ultra" of all Rhubarb, surpassing all other varieties not only in flavor and delicate tenderness of its crimson stalks, but also in size, the actual wcight of twelve stalks being eleven pounds and one ounce.

Those who have never tasted Champagne Rhubarb will have a real surprise. With this variety it is possible to have Rhubarb on your table from Spring unti Autumn. It will supply an abundance of appetizing sauce and pies. Few private gardens are without this healthful vegetable and none should be. Its culture is the simplest.

Prices for Strong, two-year old plants, $\$ .50$ each, $\$ 3.00$ per doz. $\$ 15.00$ per 100

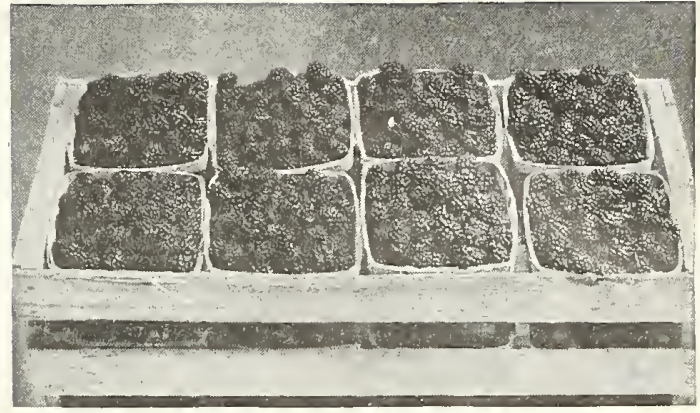

One Crate of Sixteen Quarts From Six Plants

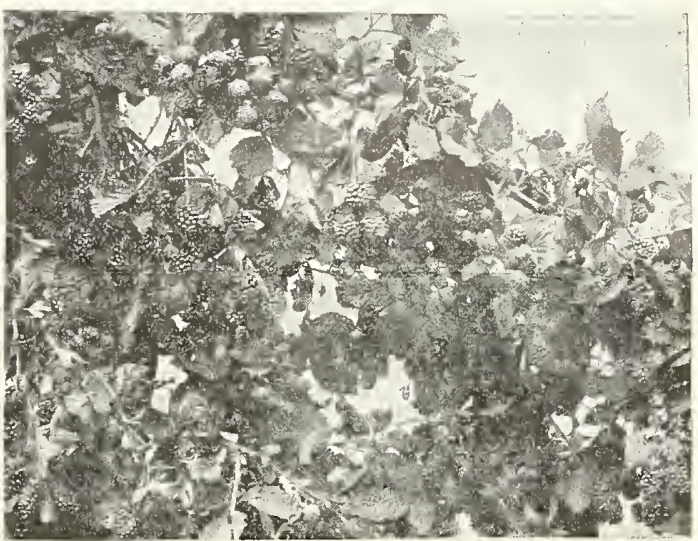

2694 Berries on One Plant

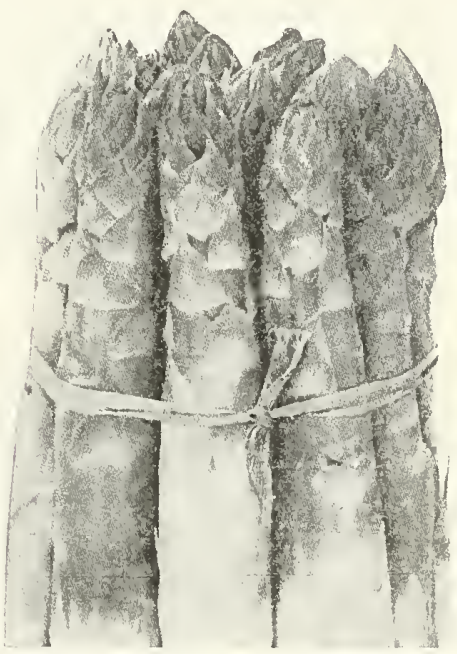

You Can Easily and at Small Cost Have Your Own Asparagus Bed Next Summer by Planting This Fall.

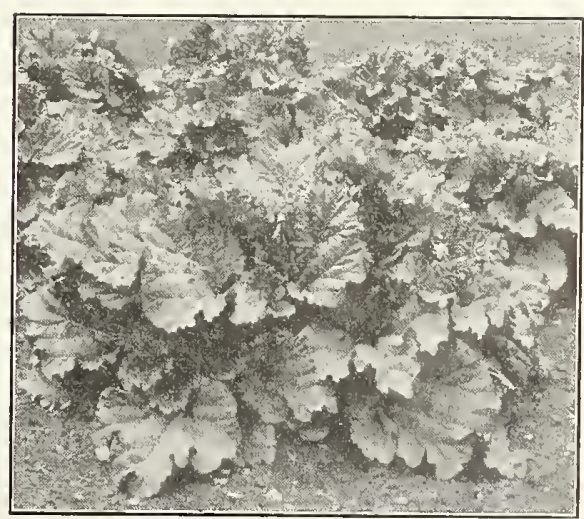

Have You a Waste Space in Your Yard? Plant A Few Champagne Rhubarb 


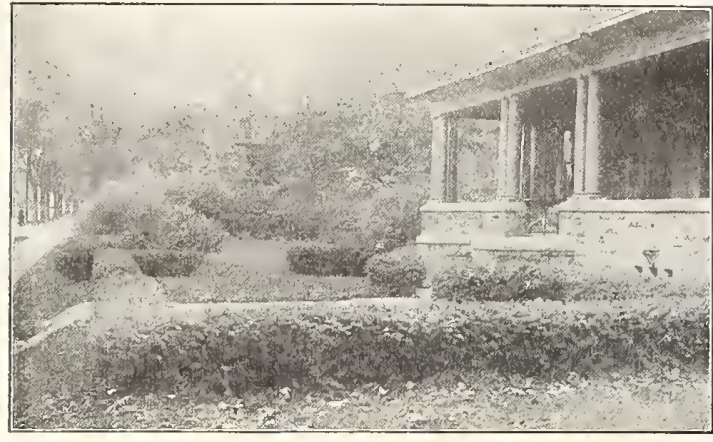

The Greatest of Hedge Plants-Never Winter-Kills

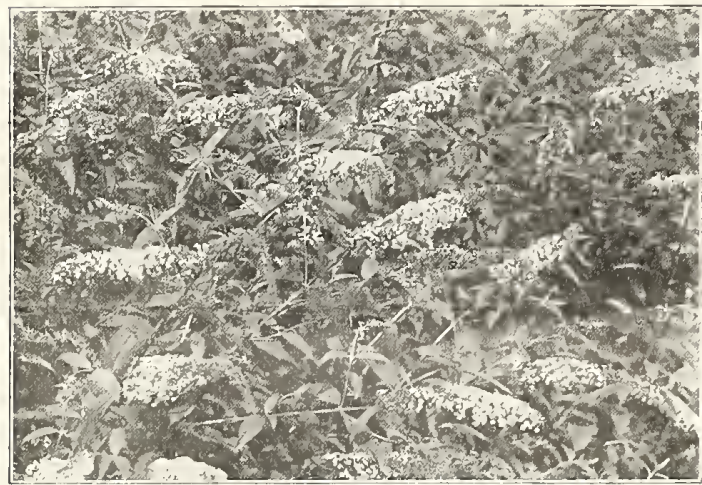

Make Room for a Plant or Two of the Butterfly Bush-It Attracts the Butterflies

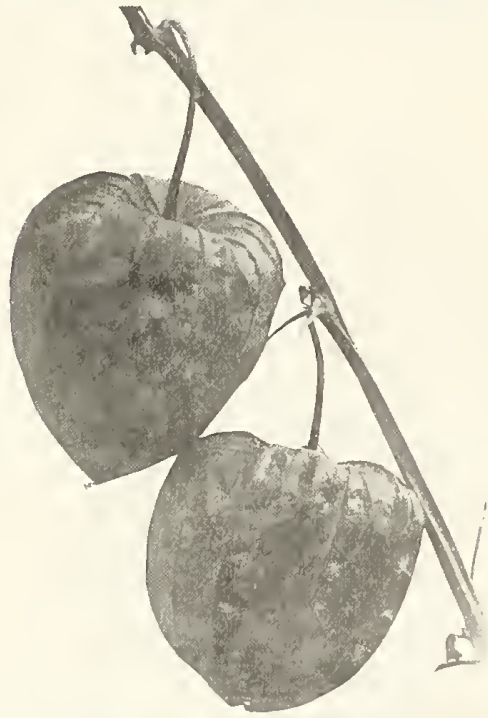

Not only a Hardy Out-Door Plant, But a Desirable House Plant

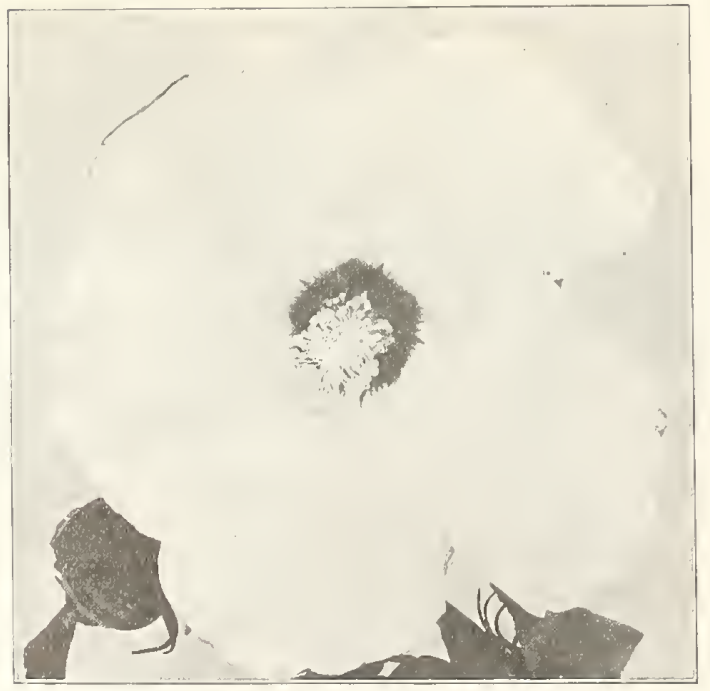

Flowers Ten Inches in Diameter
GLEN BROS., Inc., Glenwood Nurseries, Rochester, N. Y.

\section{PLANT THIS FALL}

\section{An Ideal Hedge, Barberry Thunbergii}

\section{JAPANESE BARBERRY}

A recent introduction and one of the most ornamental and valuable new shrubs; remarkable for its dense spreading growth, its hardiness and attractive appearance throughout the year One of the earliest to start in the spring; before most other plants have awakened from their winter sleep it is covered with the greenness of its dainty little leaves and a few weeks later with myriads of small pale yellow flowers, followed by an abundant crop of fruit, ripening into scarlet berries which remain to make the bush a conspicuous and attractive object all winter. The brilliant autumn coloring of the leaves, which assume the brightest shades of orange, scarlet, and crimson, is not the least of the attractions of this interesting bush. It is one of the best plants for shrubbery borders, for edging and for hedges. By trimming it can be kept of any size or shape desired, or if allowed to grow without interruption it will make a defensive hedge four or live it. high, and six or eight ft. broad. Its thorns though not long are very sharp, and severe enough to bar all but the most deterinined intruders. Set one foot apart.

Prices,

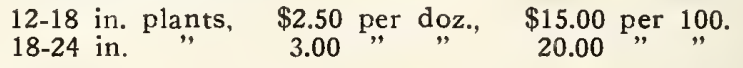

\section{Butterfly Bush}

The name BUTTERFLY BUSH was applied to it because it seems to attract butterflies in large numbers. Particularly we notice that it is not alone the common little yellow species of butterfly, but also the large and gorgeously colored butterflies that swarm about it as though vieing with it in brilliancy of color. This shrub from a young plant set out in the fall will mature to full size the first summer, producing a handsome bush, which the first year often attains a height of four $\mathrm{ft}$. It produces long, graceful stems, which terminate in tapering panicles of beautiful lilac-colored flowers that are of minature size and borne by the hundreds on a flower head which is frequently ten inches long. A single plant the first season will throw out as many as fifty flower spikes, which increase greatly in number during succeeding years. The year after planting it generally commences to flower in June, and continuing each season until severe frosts nip it. The foliage and blooms are exceedingly fine. This shrub is very desirable as an individual specimen in the lawn and garden, or placed promiscuously in the shrubbery border.

Price, $\$ .75$ each $\$ 7.50$ per doz.

\section{Lantern Plant}

This is the finest of this large class and is much prized for its large glowing red calyxes, which develop as the frut ripens. It is a most striking and showy plant and very easy to grow.

This interesting plant grows about two ft. high and is well adapted for beds or borders, and in the late summer and fall when covered with its large brilliant colored pods, inside of which the fruit develops, is exceedingly attractive.

The effect the ripened fruit among the bright green foliage is singularly striking, and in the husk or lanterns a fruit is borne, much like a Winter Cherry or Husk Tomato except the color is a deep ruby red, and is in every way superior either for cooking, preserving or eating raw.

Branches covered with lanterns are used with splendid effect as parlor ormaments or Christmas-tree decorations retaining their shape and color for nearly a year. They make an unusually elegant appearance when arranged in vases with tall dried grasses.

For all ornamental purposes it is an exceedingly valuable novelty, and will give the best of satisfaction. As a winter blooming pot plant it will be hard to find its equal.

Price, $\$ 1.00$ each, $\$ 10.00$ per doz.

\section{Marvelous Giant Redflowering Mallow}

King of all hardy plants. Perfectly hardy in any climate, and when in full bloom is a flower show in itself. Every garden and lawn should have one or more of these marvelous plants.

Right in the middle of summer, the rich, glorious red flowers of this wonderful creation are beginning to open, and they continue until "Jack Frost" arrives.

Can you realize how large these blooms are? Imagine flowers six to ten inches in diameter, in fact, the size of a dinner plate. They are simply gorgeous. Every flower delights the eye. It will when in bloom overshadow every other plant or shrub on the lawn. Those who see it for the first time say the mass of brilliant color "almost takes their breath away."

These plants come up each year from the same roots, develop into bushes ix to eight $\mathrm{ft}$. high and have beautiful foliage. They are as hardy as a rock. In Canada they have lived through the severest winters, and in the South have been equally satisfactory.

Our Stock of the Giant Red Mallow is large and we have priced them so that all may enjoy their wonderful display.

Price, $\$ .50$ each, $\$ 5.00$ per.doz. 
GLEN BROS., Inc., Glenwood Nurseries, Rochester, N. Y.

\section{Paeonies}

Fall Planting Insures Profuse Blooming Next Summer

Last year our Landscape Department prepared a Paeonia bed for one of our good Rochester customers, which has attracted so much attention this summer that we have decided to give each and every one of our customers the opportunity of having one of these beds in bloom next summer. The planting plan shown, provides for 12 of our choicest varieties arranged to the best advantage, and for $\$ 5.00$ there is nothing in our entire stock of trees and plants that will give you so much real pleasure and satisfaction with scarcely any trouble or bother. Order to-day for fall shipment.

$\$ 5.00$ is all it costs.

1. Festiva Maxima,-Pure white flecked with carmine; very large, rose type; free flowering; fragrant, medium early.

2. L'Eclatante,-Brilliant red; very large bomb type; strong growing; midseason

3. Rubens,-Very dark crimson; large semi-double type; fragrant early. Extra fine variety.

4. Edulis Superba,---Bright mauve pink; large, rather flat, crown type; strong, upright grower, free bloomer, fragrant; early.

5. Delachi,-Rosy magenta; large, rose type; very fine bloomer; late. Extra fine variety.

6. Queen Victoria,--Milkwhite guards tinted flesh, the center creamy white with crimson spots; medium sized bomb type; free blooming, fragrant mid-season.

7. Duchess de Nemours,-Pure white; medium sized, crown type; fragrant two days earlier than Festiva Maxima.

8. Louis VanHoutte,-Dark red, medium sized, semi-double type, fragrant, late.

9. Meissonier,--Reddish purple, medium sized bomb type; free flowering; fragrant mid-season.

10. Mme. Calot,-Pale, hydrangea-pink, center shaded darker; large rose type, free flowering, fragrant, early. Very good.

11. Agida,-Violet Rose; early bloomer, free flowering, semidouble type of medium size.

12. Duke of Wellington,-White with sulphur center; large ,bomb type; very free bloomer; very fragrant, late.

\section{Honeysuckle}

HONEYSUCKLE, (Ruprechtiana)-A rare Chinese variety of iron-clad hardiness, strong, rapid growth, enduring drouth beyond other varieties. Its pure white, fragrant flowers, followed by red berries loved by the birds, make it almost indispensible to all lovers of the beautiful. Strong, nursery grown plants, 3-4 ft. for immediate effect, $\$ .50$ each, $\$ 5.00$ per doz.

Its beautiful foliage, and hardiness make it a valuable hedge shrub. Planted $2 \mathrm{ft}$. apart. For this purpose smaller plants are used, $\$ 30.00$ per 100 .

\section{Syringa (Philadelphus)}

\section{Mock Orange}

MER DE GLACE.-A new hybrid of Mr. Lemoine's, who has introduced nearly as many varieties of these sweet scented shrubs as he has of the lilacs. A vigorous grower, very free flowering, with pure white double flowers, delightfully fragrant, surprisingly beautiful. Awarded first-class certificate N. H. S.

Strong nursery grown plants, $2-3$ ft. $\$ .75$ each, $\$ 6.00$ per doz.

\section{Hydrangea Arborescens Sterilis}

Popularly called the Snowball Hydrangea, producing "Hills of Snow" from June until Fall.

This new shrub is fast taking the place in public favor so long held by Hydrangea Paniculata Grandifiora. The flowers are purer white than those of the Hydrangea Paniculata Grandifiora, are quite as large and are borne in as great or greater profusion, remaining on the bush long after the foliage has disappeared and well into the winter.

It has all the good qualities of the Hydrangea Paniculata Grandiflora, and others peculiarly its own. While quite as bold and striking in its general characteristics it is coupled with a grace and elegance not found in the old favorite. Its foliage is much finer than that of the well known Hydrangea Paniculata Grandifiora. Every shoot terminates in a showy bloom cluster. It produces from July until fall a bewildering profusion of fower heads, resembling giant snowballs-and much handsomer than those of other Hydrangeas.

Price, $\$ .50$ each, $\$ 5.00$ per doz.

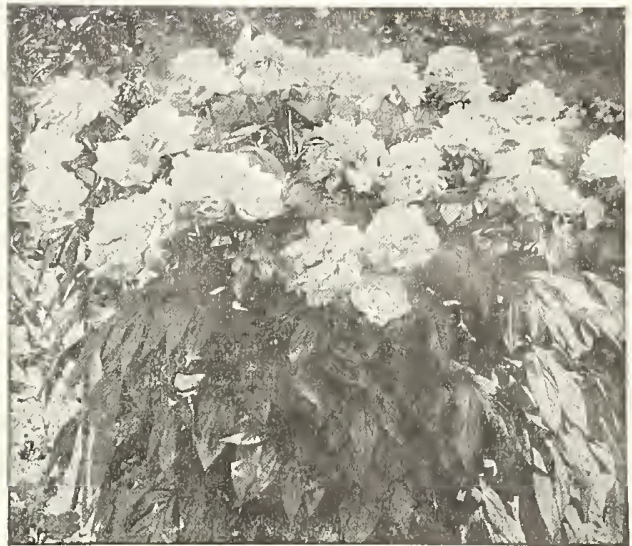

Paeonies Rival the Rose in Beauty, Form and Exquisite Coloring and

\begin{tabular}{|c|c|c|c|c|}
\hline (1) & (3) & (5) & (7) & (9) \\
\hline (4) & (6) & (8) & (10) & (12) \\
\hline
\end{tabular}

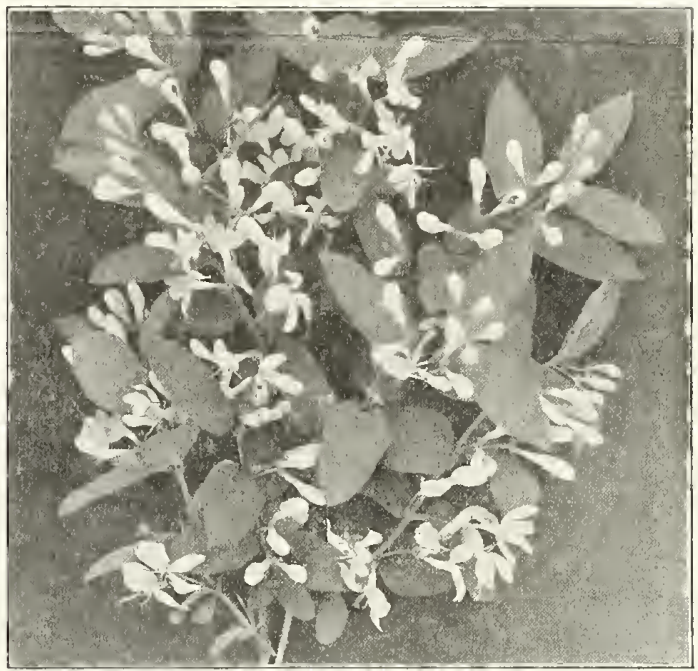

Manchurian is a Real Hardy Honeysuckle

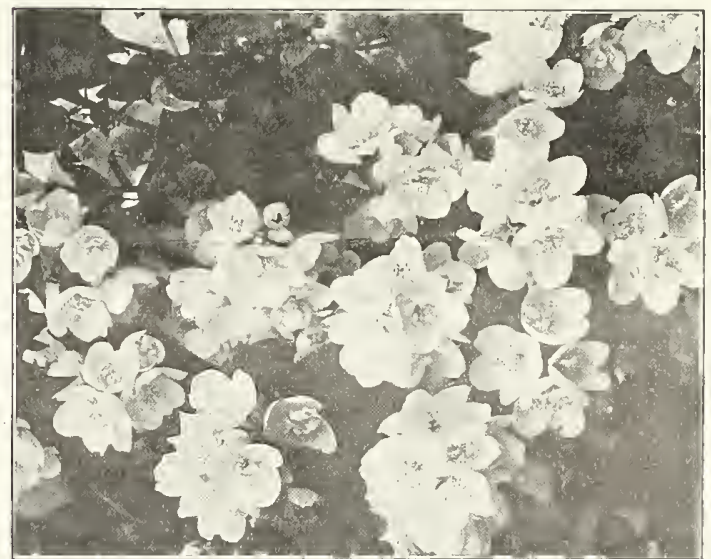

The Bouquet Syringa. Sounds Good-It is Good.

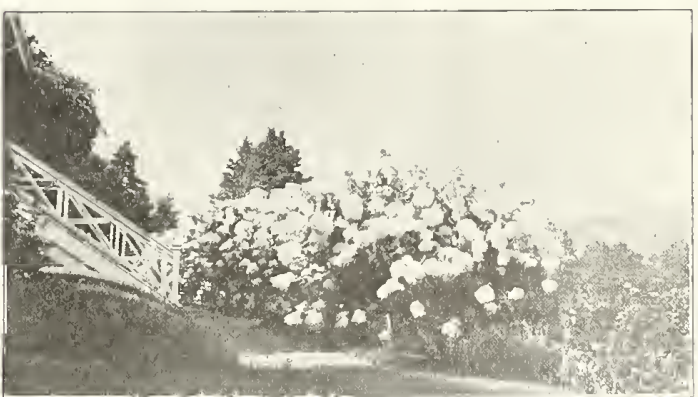

3,000 Perfect Blooms on Eight Plants 


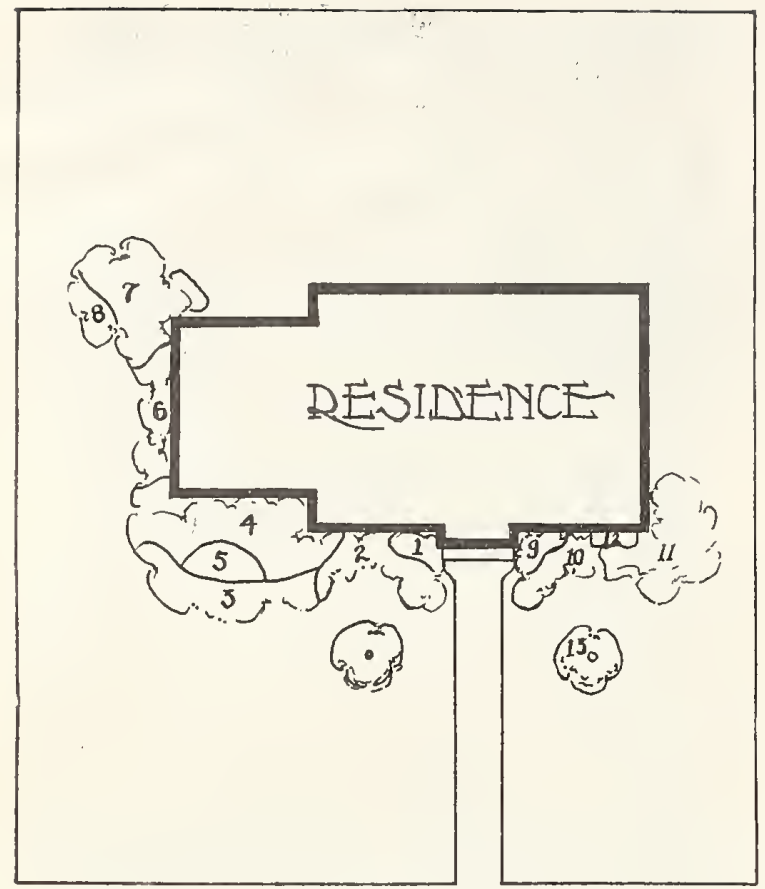

YaนK

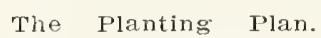

No. 1-Honeysuckle Ruprechtiana,

2-Deutzia, Lemoine's

3-Lemoine's Deutzia,

4-Lilacs, Common.

5-Smoke Tree,.

6-Jap. Barberry,

7-Hydrangea, P. G.

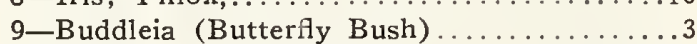

10-Deutzia, Lemoine's,............... 6

11-Dogwood Red Brand,.............. 6

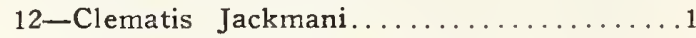

13-Specimen Shade Trees, 8-10 ft.........2

THE PLANTING LIST

The first number refers to plan, the second number indicates estimated quantity.

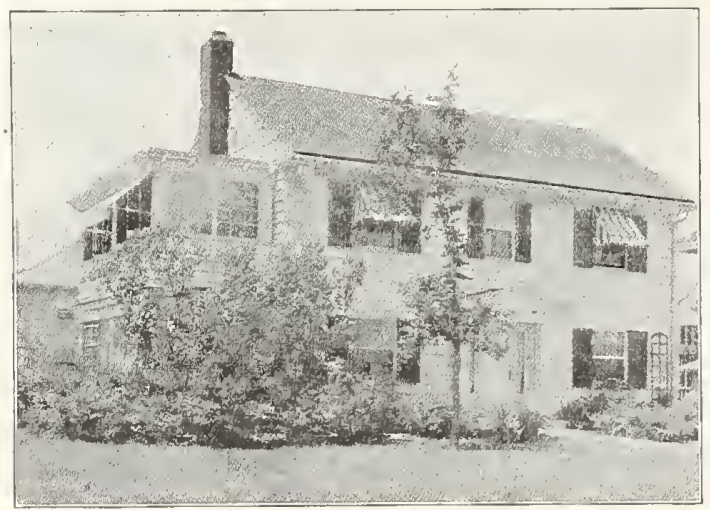

The Plan Properly Executed-Entire Cost Exclusive of Planting, $\$ 30.00-W e$ Can Do Equally as Well for You

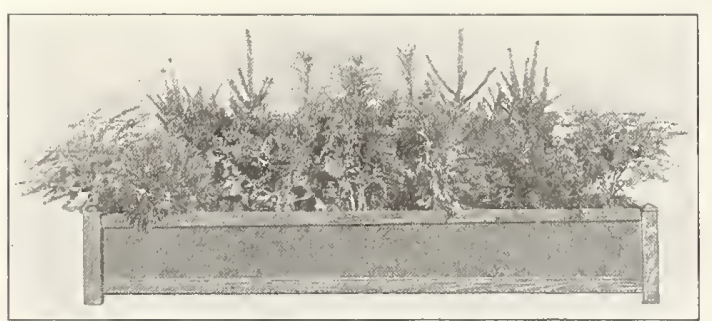

Adds Coziness and Attractiveness During the Long Winter Montlis
GLEN BROS., Inc., Glenwood Nurseries, Rochester, N. Y.

\section{Landscape Department}

Back of every Landscape plan we make is 53 year's experience.

\section{We Will Make Your Garden Bloom From Spring- time Until Frost}

Let us advise you as to how you can secure the utmost Beauty and Delight from your garden. We offer the advice and service of our Landscape Architects and Gardeners to assist you in making your surroundings more beautiful.

A plan for laying out grounds properly is as necessary as a plan for building a house. A mistake made in the beginning often costs many times the small expense of plan, or having a landscape architect view the grounds, to say nothing of the annoyance and delay in securing the desired effect.

ON THE FOLLOWING TERMS WE WILL MAKE A SKETCH, showing how to lay out and plant your grounds in an artistic and attractive way. Send us a rough sketch of your grounds, showing location of buildings, walks, drives, if any, also trees and shrubbery or any other permanent things already established, and that are not to be removed. Show location of all the entrances to lot and buildings, any objectionable or desirable views from the residence, and grades of any importance. Photographs will also be of valuable assistance if convenient to send. The sketch need not be drawn to scale, but should show the width and depth of the lot and other principal dimensions.

When the sketch is sent to us, remit $\$ 2.00$, for which we will at once send a credit memorandum for the amount, and this credit memorandum will be accepted by us as part payment on an order amounting to $\$ 15.00$ or more. We wish to impress upon the minds of our customers that this is not a scheme of any kind by which we are receiving pay for the sketch, but it is done only as a safe-guard against some curious persons that would impose upon us and ask for plans with little or no intention of making use of them. These plans we furnish are not stock plans, but you will receive a plan made especially for your own grounds. The planting arrangement is worked out by our Landscape Architects to meet the requirements of your place. We make plans for the surroundings of the humblest little cottage as well as the extensive and elaborate estate, public parks, factory grounds, school universities, sanitariums, etc.

NOTE-The above arrangement, however, applies principally to home grounds of moderate size, and not to extensive or elaborate grounds where a large amount of work is involved. We are prepared also to do this class of work, and solicit correspondence from parties desiring such work. We furnish plans by mail, or when desired, will send a landscape architect to do the work or instruct you how to do it. Our terms for this class of work are always very reasonable.

\section{WE DESIGN AND PLANT LARGE PUBLIC AND PRIVATE GROUNDS} OF ALL KINDS

Planting and furnishing stock for Parks, liactory Grounds, Schools, Universities Sanitariums, and Hotel Grounds is one of our specialties, and we are prepared to plan and advise how and what to plant to produce the best results and with the least amount of labor and expenditure. Call on us when in need of such service; we assure satisfaction.

OUR EXPERTS GO EVERYWHERE TO PLAN AND PLANT

\section{Small Evergreens}

\section{For Window and Porch Boxes for Winter Decoration}

Very tasty boxes can be made up with various arrangements of Evergreens. There are a number of ways of filling boxes. Placed closely together all of the same height, giving a hedge-like appearance high at the ends, and low in the center, affords, with a little clipping, a graceful curved effect. Tall trimmed plants at the end, with a lower compact line, straight across presents a good appearance. Each tree planted so as to show its individuality, is another plan, While a box filled with a number of varieties gives a shaded color effect that is very attractive. The outside decoration of business houses, hotels, restaurants, city and suburban dwellings with hardy, ornamental evergreens, is rapidly becoming the custom in all the large towns and cities.

\section{EVERGREENS FOR WINDOW-BOXES}

Especially grown, bushy, symmetrical stock.

\begin{tabular}{|c|c|}
\hline Black Hill Spruce & $\begin{array}{r}10-12 \text { in. } \\
6-10 \text { in. }\end{array}$ \\
\hline Mugho Pine & $\begin{array}{r}10-12 \text { in. } \\
6-8 \text { in. }\end{array}$ \\
\hline American Arbor Vitae & $\begin{array}{r}12-18 \text { in. } \\
6-8 \text { in. }\end{array}$ \\
\hline
\end{tabular}

